\title{
Physicochemical and Microbiological Studies of Urine Contaminated Soil in Abia State University, Uturu Campus
}

\author{
Chukwu Vince Anyim*1, Nnadozie TN², Nsemoh $\mathrm{HE}^{2}$ and Obiekezie SO${ }^{3}$ \\ ${ }^{1}$ Department of Microbiology, Federal University, Nigeria \\ ${ }^{2}$ Department of Chemistry, Federal University, Nigeria \\ ${ }^{3}$ Department of Biological Sciences, Nasarawa State University, Nigeria
}

Submission: March 07, 2018; Published: April 13, 2018

*Corresponding author: Chukwu Vince Anyim, Department of Microbiology, Federal University, P.M.B. 146, Lafia, Nasarawa State, Nigeria,

Tel: +2347032728649; Email: docvin4all@yahoo.com

\begin{abstract}
This study was carried out to investigate the physicochemical properties and microorganisms in urine contaminated soils in Abia State University, Uturu premises. Twelve samples were collected and analysed using standard techniques. Urine contaminated soils were collected from three different lecture hall areas in the university and uncontaminated soil which served as the control. The total heterotrophic bacterial counts of the urine contaminated soils ranged between $31.0 \pm 1.0 \times 104 \mathrm{cfu} / \mathrm{g}$ to $26.0 \pm 1.0 \times 103 \mathrm{cfu} / \mathrm{g}$ (New Examination hall and Biochemistry laboratory areas respectively). The total coliform counts ranged between $7.0 \pm 0.1 \times 104 \mathrm{cfu} / \mathrm{gto} 2.0 \pm 1.0 \times 101 \mathrm{cfu} / \mathrm{g}$ (New Examination hall and Biochemistry laboratory areas respectively) while the total fungal counts recorded $4.0 \pm 1.0 \times 103 \mathrm{cfu} / \mathrm{g}$ to $2.6 \pm 0.6 \times 104 \mathrm{cfu} / \mathrm{g}$ for the New Examination hall and Biochemistry laboratory areas respectively. The bacteria isolated from these soils and their percentage prevalence rates include: Bacillus spp (26.6\%), Staphylococcus spp (10.5\%), Klebsiella spp (15.7\%), Micrococcus spp (15.7\%) and Enterobcter spp (5.2\%). The fungi isolates include: Penicillium spp (10.5\%), Rhizopus spp (10.5\%) and Aspergillus spp (5.2\%). The physicochemical analysis of the urine contaminated soil samples revealed high concentrations of sulphate, nitrate, ammonia, phosphate, organic matter and moisture content. The pH values of the polluted soil samples were significantly low. The lowered $\mathrm{pH}$ values observed indicate an increased soil acidity which has an adverse effect on soil biota. The study has also revealed that soils from public urinals consist of opportunistic microbial species of importance to human and public health.
\end{abstract}

Keywords: Urine; Soil; Contaminate; Human; Public sub-theme: environmental microbiology

\section{Introduction}

Soil is a natural cultural media for the growth of many types of organism. The organic and inorganic matter in the soil determines the soil fertility and aid the proliferation of various micro flora that play vital roles in maintaining the nutritional balance of the soil Dada \& Aruwa [1].

The topsoil has the highest concentration of organic matter and microorganism and it is where most of the Earth's biological soil activity occurs. Hence, earth depends on soil to a great extent, and as human population grows, its depth, season of the year, state of the cultivation, organic demand for food from crops increases, thereby making soil conservation crucial. A few of the consequences of human activity and carelessness are deforestation, over-development, and pollution from man-made chemicals and human wastes Joanne et al. [2].

Urine is a filtered product of kidney which contains only low molecular weight substances and at excretion the $\mathrm{pH}$ is normally around 6 but can vary between 4.5 and 8.2 Lentner et al. [3]. It was further shown by Lentner et al. [3] that of the
Nitrogen constituent of urine $75-90 \%$ is excreted as Urea and the remainder as ammonium and creatinine. In the presence ofurease, urea is quickly degraded to ammonium and carbon dioxide and the hydroxide ions produced will invariably increase soil $\mathrm{pH}$ to $9-9.3$ and this usually occurs within hours of deposition Jonssen et al. [4]. But the continual deposition ofurine at a spot lead to net acidification of the soil because the conversion of ammonium (NH4) to nitrate (NO3) involves release of protons, thereby promoting acidity.

In Nigeria, urine deposition in public places go on unchecked and has become a menace, a close examination of such soil macrocosm reveals patchiness of soil, obvious discolouration, pungent ammoniacal smell (pers comm). There is therefore the need to establish the impact of human urine deposition on soil biota.

\section{Study Area}

This study was conducted within the premises of Abia State University, Uturu because of the problem of overstretched facilities, which contributed to the practice of indiscriminate 
urination around lecture halls. The study was carried out while the institution was in session

\section{Materials and Methods}

\section{Source of sample and sample collection}

Urine contaminated soil samples used in this study were collected from different sites in the institution. The sites used are the undesignated areas for urine discharge. The sites are the soil area noted for frequent urine discharge, while a meter away (not used for urine discharge) was chosen as the control. A total of 12 samples were collected from the urine soil contaminated site (3 samples each from 3 sites) and control soil site was collected from the topsoil (between 5-20 cm), respectively. Sample collection sites were the Microbiology Final year Laboratory (Sample A), Biochemistry Laboratory Hall (Sample B) and the New Exam Hall (Sample C). Samples from contaminated soils and control area (Sample D) were collected in separate sterile polythene bags, which were sealed, respectively and were appropriately labeled (A-D) before they were transferred to Microbiology Laboratory for immediate analysis (within $24 \mathrm{hrs}$ of sample collection).

\section{Determination of Microbial Loads of the Samples}

The microbial loads of various groups of bacterial species were determined using the culture techniques involving different culture media. The different soil samples were analyzed for the microbial diversity as described earlier in the sample collection. Bioloads were determined after decimal serial dilutions. $9 \mathrm{mls}$ of distilled water were pipetted into ten testtubes prepared in duplicate and labeled 101 to 1010 for serial dilution. $1 \mathrm{ml}$ was taken from the stock sample and put into 10-1 tube, this was mixed properly and from this $10-1,1 \mathrm{ml}$ was transferred into 10-2 tube. This was repeated, till the 10-9 tube using fresh $5 \mathrm{ml}$ pipette at each interval. $1 \mathrm{ml}$ was discarded from the last tube to make all equal $(9 \mathrm{ml}$ each). $0.2 \mathrm{ml}$ aliquots from the $10-9$ tubes were aseptically inoculated onto different culture media (agar) using the spread plate techniques. Bacterial cultures were incubated at 370C for 24-48 hours while the fungal cultures were incubated at ambient laboratory temperature $(28 \pm 20 \mathrm{C})$ for 2-5 days with daily observation.

Results

Table 1: Total Microbial Counts of the Urine Contaminated Soil.

\begin{tabular}{|c|c|c|c|}
\hline Samples & THBC & TCC & TFCC \\
\hline A & $28.0 \pm 1.0 \times 102$ & $4.0 \pm 1.0 \times 104$ & $3.0 \pm 1.0 \times 103$ \\
\hline B & $26.0 \pm 1.0 \times 103$ & $2.0 \pm 1.0 \times 101$ & $2.6 \pm 0.6 \times 104$ \\
\hline C & $31.0 \pm 1.0 \times 104$ & $7.0 \pm 0.1 \times 104$ & $4.0 \pm 1.0 \times 103$ \\
\hline D & $153.3 \pm 1.5 \times 103$ & $60.0 \pm 1.0 \times 103$ & $12.0 \pm 2.0 \times 103$ \\
\hline
\end{tabular}

Values are means of three replicates and are expressed as mean \pm standard deviation.

At $\mathrm{P}<0.05$, there is significant differences

Keys:

Samples

A=Microbiology Laboratory Hall
Various culture media were used. These were Nutrient Agar for Total Heterotrophic Bacterial Count (THBC), MacConkey Agar for Total Coliform Counts (TCC), EMB Agar for Total Faecal Coliform Counts (TFCC) and Sabouraud Dextrose Agar for Total Fungal Counts (TFC). Counting was done using colony counter.

\section{Isolation and identification of observed isolates}

Pure bacterial isolates were identified based on their characteristics such as morphology, microscopy, staining ability and their biochemical reactions. The bacteria were stained using Gram's staining, spore staining and capsule staining methods.

\section{Identification of Fungal Isolates}

The samples were analysed for fungal isolates on Sabouraud Dextrose Agar. On establishment of growth after 2-4days of incubation at room temperature, the plates were carefully examined and distinct growths were sub-cultured on fresh medium for purity. The fungi were then identified on the basis of their cultural characteristics and microscopy with reference to the methods described by Barnett et al. [4].

\section{Physicochemical analysis of soil}

At the laboratory, $2 \mathrm{~mm}$ and $0.5 \mathrm{~mm}$ mesh-size sieves were used to sieve the soil samples. The sieved soil samples were analysed for $\mathrm{pH}$, Moisture content (MC), organic carbon (OC), organic matter $(\mathrm{OM})$, phosphate, ammonium, nitrate, sulphate. $\mathrm{pH}$ was determined using the $\mathrm{pH}$ meter. $\mathrm{MC}$ was determined by drying and difference in weight method. OC was determined using the Walkey-Black method and \% OM was estimated by the formula $\% 0 \mathrm{OC}=0 \mathrm{Cx} 1.729$. Phosphate and nitrate were determined by spectrophotometric method while sulphate was determined by the turbidimetry method. Ammonium is determined by distillation method using $40 \%$ boric acid with methyl red indicator.

\section{Statistical analysis}

The results obtained in this study were subjected to standard statistical analysis by the use of correlation analysis, standard deviation and ANOVA. This was used to determine the significance of the results. 
B=Biochemistry Laboratory Hall

$\mathrm{C}=$ New Examination Hall

$\mathrm{D}=$ Uncontaminated Soil

Table 1 shows the total microbial counts observed for bacteria and fungi from urine contaminated and control soils, respectively. The highest total hetrotrophic bacterial counts was observed for soil samples from New Examination hall area $31.0 \pm 1.0 \times 104 \mathrm{cfu} / \mathrm{g}$, this is followed by soil samples from Microbiology laboratory area $28.0 \pm 1.0 \times 102 \mathrm{cfu} / \mathrm{g}$ while the least counts was observed for soil samples from Biochemistry laboratory area $26.0 \pm 1.0 \times 103 \mathrm{cfu} / \mathrm{g}$. The total coliform counts ranged from $7.0 \pm 1.0 \times 104$ to $2.0 \pm 1.0 \times 104 \mathrm{cfu} / \mathrm{g}$ for soil samples from New Examination hall area and Biochemistry Laboratory area respectively. The total fungal counts was observed highest in soil samples from New Examination hall area
$(3.0 \pm 1.0 \times 103 \mathrm{cfu} / \mathrm{g})$ and the least counts for soil samples from Biochemistry laboratory area $2.6 \pm 0.6 \times 104 \mathrm{cfu} / \mathrm{g}$. For the control sites, highest counts were observed for the total heterophic bacterial counts $(153.30 \pm 1 . \times 104 \mathrm{cfu} / \mathrm{g})$ and the least counts for the total fungal counts $(12.0 \pm 2.0 \times 103 \mathrm{cfu} / \mathrm{g})$.

Table 2 shows the result of the physicochemical analysis of the soil samples. The Organic matter (OM), organic carbon (OC), Moisture Content (MC), P04, NH4, NO3 and SO4 were significantly higher $(\mathrm{p}<0.05)$ in urine contaminated soil samples (UrCS) than uncontaminated soil (UnCS) samples while $\mathrm{pH}$ was significantly lower

Table 2: Physicochemical Analysis of the Soil Samples.

\begin{tabular}{|c|c|c|c|c|}
\hline Parameters & A & B & C & D \\
\hline $\mathrm{pH}$ & $4.00 \pm 0.2$ & $4.5 \pm 0.4$ & $5.0 \pm 0.1$ & $7.5 \pm 0.6$ \\
\hline $\mathrm{SO}_{4}$ & $0.004 \pm 0.02$ & $0.005 \pm 0.01$ & $0.004 \pm 0.001$ & $0.002 \pm 0.002$ \\
\hline $\mathrm{NO}_{3}$ & $0.009 \pm 0.001$ & $0.007 \pm 0.001$ & $0.006 \pm 0.01$ & $0.005 \pm 0.01$ \\
\hline $\mathrm{NH}_{3}$ & $0.019 \pm 0.001$ & $0.015 \pm 0.002$ & $0.01 \pm 0.002$ & $0.02 \pm 0.001$ \\
\hline $\mathrm{PO}_{4}$ & $0.06 \pm 0.006$ & $0.04 \pm 0.006$ & $0.04 \pm 0.004$ & $0.024 \pm 0.004$ \\
\hline Organic carbon & $1.5 \pm 0.01$ & $1.2 \pm 0.01$ & $0.9 \pm 0.002$ & $0.5 \pm 0.005$ \\
\hline Organic matter & $5.9 \pm 1.8$ & $4.5 \pm 1.7$ & $7.0 \pm 1.4$ & $1.6 \pm 0.10$ \\
\hline Moisture content & $19.5 \pm 0.6$ & $14.2 \pm 0.05$ & $21.0 \pm 0.06$ & $8.0 \pm 0.02$ \\
\hline
\end{tabular}

Values are means of three replicates and are expressed as mean \pm standard deviation.

At $\mathrm{P}<0.05$, there is significant differences

Keys:

Samples

A=Microbiology Laboratory Hall

B=Biochemistry Laboratory Hall

$\mathrm{C}=$ New Examination Hall

$\mathrm{D}=$ Uncontaminated Soil

Table 3 \& 4 reveal the bacteria and fungi isolates from urine contaminated soil samples. They include: Bacillus spp, Staphylococcus spp, Enterobacter spp, Klebsiella spp and Micrococcus spp. The fungi isolates include: Aspergillusspp, Penicilliumspp, Rhizopus spp and Trichophyton spp. Table 5\&6

show the occurrence and percentage occurrence of the microbial isolates from the urine contaminated soil samples respectively. Bacillus spp recorded the highest percentage rate of occurrence (26.6\%), this is followed by Staphylococcus spp, Rhizopus spp and Penicillium spp (15.7\%).

Table 3: Identification of Bacteria Isolated From the Various Urine Contaminated Soil Samples

\begin{tabular}{|c|c|c|c|c|c|c|c|c|c|c|c|c|c|c|c|c|c|c|c|c|c|}
\hline \multicolumn{5}{|c|}{ Microscopy } & \multicolumn{10}{|c|}{ Biochemical Reactions } & \multicolumn{7}{|c|}{ Carbohydrate Utilization } \\
\hline $\begin{array}{l}\text { COLONY } \\
\text { FEATURES }\end{array}$ & $\begin{array}{c}\text { Arra } \\
\text { ngem } \\
\text { ent }\end{array}$ & $\begin{array}{l}0 \\
\text { ڤั } \\
\text { के }\end{array}$ & 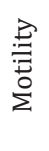 & $\begin{array}{l}\frac{0}{\overrightarrow{7}} \\
\text { 足 } \\
\text { ज़ }\end{array}$ & $\begin{array}{l}\ddot{y} \\
\frac{\pi}{\pi} \\
\tilde{\pi} \\
\tilde{J}\end{array}$ & $\begin{array}{l}0 \\
\tilde{n} \\
\frac{\pi}{0} \\
\frac{\pi}{\tilde{x}}\end{array}$ & 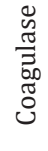 & $\begin{array}{l}\frac{0}{0} \\
\frac{\pi}{\Xi}\end{array}$ & 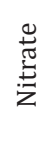 & 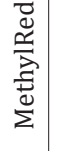 & $\stackrel{3}{>}$ & 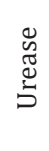 & $\underset{I}{\tilde{I}}$ & 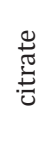 & 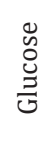 & 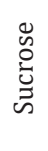 & 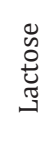 & 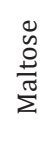 & 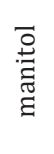 & 崖 & $\begin{array}{c}\text { ORGAN } \\
\text { ISM }\end{array}$ \\
\hline
\end{tabular}




\begin{tabular}{|c|c|c|c|c|c|c|c|c|c|c|c|c|c|c|c|c|c|c|c|c|c|}
\hline $\begin{array}{c}\text { Circular } \\
\text { smooth } \\
\text { colonies } \\
\text { with light- } \\
\text { yellow } \\
\text { pigments } \\
\text { on } \\
\text { Mannitol } \\
\text { Salt Agar } \\
\text { (MSA). }\end{array}$ & $\begin{array}{c}\text { Gram } \\
\text { posi } \\
\text { tive } \\
\text { Group } \\
\text { of oval } \\
\text { cells }\end{array}$ & - & - & - & + & & + & + & + & + & + & + & + & & + & + & + & + & + & + & $\begin{array}{c}\text { Stap } \\
\text { hylo } \\
\text { coccus } \\
\text { spp }\end{array}$ \\
\hline $\begin{array}{l}\text { Large } \\
\text { mucoid } \\
\text { pink } \\
\text { colonies on } \\
\text { MA }\end{array}$ & $\begin{array}{c}\text { Gram } \\
\text { nega } \\
\text { tive } \\
\text { short } \\
\text { rods } \\
\text { in } \\
\text { sing } \\
\text { les }\end{array}$ & - & - & + & - & - & - & - & + & - & + & + & - & + & + & - & + & - & - & - & $\begin{array}{c}\text { Klebsiella } \\
\quad \text { spp }\end{array}$ \\
\hline $\begin{array}{l}\text { Cream } \\
\text { raised dull } \\
\text { colonies, } \\
\text { waxy with } \\
\text { projection } \\
\text { margins }\end{array}$ & $\begin{array}{c}\text { Gram } \\
\text { pos } \\
\text { itive } \\
\text { rods } \\
\text { in } \\
\text { pairs } \\
\text { and } \\
\text { some } \\
\text { sin } \\
\text { gles }\end{array}$ & + & - & + & + & - & - & - & - & - & - & - & - & + & + & + & + & + & - & - & $\begin{array}{c}\text { Bacillus } \\
\text { species }\end{array}$ \\
\hline $\begin{array}{l}\text { Smooth } \\
\text { cream } \\
\text { colonies } \\
\text { and } \\
\text { translucent } \\
\text { on NA }\end{array}$ & $\begin{array}{c}\text { Gram } \\
\text { posi } \\
\text { tivec } \\
\text { occi in } \\
\text { clus } \\
\text { ters } \\
\text { and } \\
\text { some } \\
\text { in tet } \\
\text { rads }\end{array}$ & - & - & - & + & + & - & - & - & + & + & - & - & + & + & + & + & + & - & + & $\begin{array}{l}\text { Microc } \\
\text { occus } \\
\text { species }\end{array}$ \\
\hline $\begin{array}{l}\text { Large } \\
\text { mucoid } \\
\text { pink } \\
\text { colonies on } \\
\text { MA }\end{array}$ & $\begin{array}{c}\text { Gram } \\
\text { neg } \\
\text { ative } \\
\text { short } \\
\text { rods in } \\
\text { sing } \\
\text { les }\end{array}$ & - & + & + & - & - & - & - & + & - & + & + & - & - & + & + & - & - & + & - & $\begin{array}{l}\text { Enterob } \\
\text { acter } s p .\end{array}$ \\
\hline
\end{tabular}

KEY: + = Positive, - = Negative, V.P = Voges-Proskauer, NA = Nutrient Agar, MA = MacConkey Agar .

Table 4: Identification of Fungi Isolated From the Various Urine Contaminated Soil Samples.

\begin{tabular}{|c|c|c|c|c|c|}
\hline Microscopy & \multicolumn{5}{|c|}{ Macroscopy/Colony Morphology } \\
\hline Characteristics & Nature of colony & Reverse side & Texture & Nature of growth & Organism \\
\hline $\begin{array}{c}\text { Septate hyphae with lateral tear- } \\
\text { shaped long microconidia. }\end{array}$ & White fluffy surface & Deep red & Fluffy & Slow & Trichophyton spp \\
\hline
\end{tabular}




\section{Current Trends in Biomedical Engineering \& Biosciences}

\begin{tabular}{|c|c|c|c|c|c|}
\hline $\begin{array}{l}\text { Unbranched conidiophore } \\
\text { and septate hyphae. Smooth } \\
\text { conidiophore with variable } \\
\text { lengths. Sterigmata covers the } \\
\text { rside and forms a radiate head. }\end{array}$ & $\begin{array}{c}\text { Black powdery, } \\
\text { myceliated, spreading }\end{array}$ & Yellow & Velvety & Rapid & Aspergillus spp \\
\hline $\begin{array}{l}\text { Numerous stolons run among the } \\
\text { mycelia connecting groups of long } \\
\text { unbranchedsporangiosphores }\end{array}$ & $\begin{array}{l}\text { Quickly covers agar } \\
\text { surface with dense } \\
\text { white cottony mycelia } \\
\text { which later turns } \\
\text { gray. }\end{array}$ & white & woolly & Rapid & Rhizopus spp \\
\hline $\begin{array}{l}\text { Septate hyphae with branched } \\
\text { conidiosphores that have } \\
\text { secondary branches. }\end{array}$ & $\begin{array}{l}\text { White surface at first, } \\
\text { then becoming very } \\
\text { powdery, bluish green } \\
\text { with white borders }\end{array}$ & White & Powdery & Rapid & Penicillium spp \\
\hline
\end{tabular}

Table 5: Occurrence of the Organisms within the Soil Samples.

\begin{tabular}{|c|c|c|c|c|}
\hline Organisms & \multicolumn{3}{|c|}{ Samples } \\
\hline Staphylococcus spp & A & B & C & D \\
\hline Klebsiella spp & + & - & + & - \\
\hline Bacillus spp & + & + & + & + \\
\hline Micrococcus spp & + & - & + & + \\
\hline Enterobacter spp & + & + & - & - \\
\hline Trichophyton spp & - & - & + & - \\
\hline Aspergillus spp & - & - & + & + \\
\hline Rhizopus spp & + & + & - & + \\
\hline Penicillium spp & - & - & + & + \\
\hline
\end{tabular}

Keys:

A=Microbiology Laboratory Hall

$\mathrm{B}=$ Biochemistry Laboratory Hall

$\mathrm{C}=$ New Examination Hall

$\mathrm{D}=$ Uncontaminated Soil

Table 6: Percentage Occurrence of the Microbial Isolates

\begin{tabular}{|c|c|c|}
\hline Organisms & Frequency of Occurrence & Percentage Rate of Occurrence (\%) \\
\hline Staphylococcus spp & 2 & 10.5 \\
\hline Klebsiella spp & 3 & $26.6 \%$ \\
\hline Bacillus spp & 4 & 15.7 \\
\hline Micrococcus spp & 3 & 5.2 \\
\hline Enterobacter spp & 1 & 5.2 \\
\hline Trichophyton spp & 1 & 5.2 \\
\hline Aspergillus spp & 1 & 10.5 \\
\hline Rhizopus spp & 2 & 10.5 \\
\hline Penicillium spp & 2 & 100 \\
\hline Total & 19 & \\
\hline
\end{tabular}

\section{Discussion and Conclusion}

The study has revealed that soils from public urinals consist of opportunistic microbial species of importance to human and public health. Bacterial and fungal isolates obtained from sampled soils in this study are in agreement with the work of Madigan \& Martinko [5] and Dada \& Aruwa [1]. Micrococcus species though found in the sampled soils is also part of the normal flora of the mammalian skin. This organism is usually non-pathogenic and usually regarded as contaminant, and could be considered as an emerging nosocomial pathogen in immunocompromised patients and persons. Micrococcus is a genus of bacteria and it occurs in a wide range of environments including water, dust, and soil. Micrococci have been isolated from human 
skin, animal and dairy products, and beer. They are found in many other places in the environment, including water, dust, and soil. M. luteus is most common and is found in nature and in clinical specimens. Micrococci can grow well in environments with little water or high salt concentrations. Though not a spore former, Micrococcus cells can survive for an extended period of time Greenblat et al. [6]. Micrococcus is generally thought to be a saprotrophic or commensal organism, though it can be an opportunistic pathogen, particularly in hosts with compromised immune systems, such as HIV patients Smith et al..

Collectively, the aerobic spore forming genus of Bacillus species are versatile chemoheterotrophs capable of respiration using a variety of simple organic compounds (sugars, amino acids, organic acids). B. cereus is a pathogen of humans (and other animals), causing food borne illness (diarrhoeal-type and emetic-type syndromes) and opportunistic infections (endophtalmia, keratitis, septicemia, meningitis, endo-carditis, pneumonia, osteomielitis, urinary infections, cutaneous infections. It also causes infections in domestic animals (mastitis and abortion in cattle) Logan [7].

Staphylococcus is a genus of round, parasitic bacteria, commonly found in air and water and on the skin and upper part of the human pharynx. These bacteria are known to cause pneumonia and septicemia as well as boils and kidney and wound infections. Staphylococcus epidermidis does not usually cause infection, occurring universally in a harmless symbiotic relationship. It is usually present on most areas of the skin, in the nostrils, mouth, external ear, and urethra. However, S. epidermidis can take advantage of a host with a suppressed immune system and can aggravate an existing condition. Following heart surgery, S. epidermidis may cause endocarditis.

Low bacterial and fungal counts could be attributed to factors such as the nature of the soil, organic matter present, and season (rainy) of the year, and agrees with the report of Bridge \& Spooner [8]. The presence of high organic matter, practice of frequent urination, regular hand washing and disposal wastewater from the laboratory may have accounted for the high counts obtained from soils from the Microbiology urinal area. Erosion may have also contributed to the washing away of microorganisms from one area to another.

Spores of Aspergillus spp when inhaled can produce pulmonary infection, allergies, eye, and ear infection. This fungus has been implicated as being one of the causes of systemic fungal diseases in humans and animals, causing acute and chronic respiratory tract infections. Aspergillosis is an infection of the skin, nasal sinuses, and lungs or other internal organs caused by molds of the genus Aspergillus. The disease is contracted by the inhalation of spores Cheesebrough [9].

Public urinal soils may become major factors in the spread of infection especially when adequate sanitary facilities are not available. Microorganisms from public urine contaminated soils have potential to cause disease either as primary or opportunistic pathogens. The stench from these urine contaminated soils is also nauseating. Organisms found in the urine contaminated soils may be attributed to persons with UTIs excreting higher amounts microflora than apparently healthy individuals. Regular visits to the public urinals may contribute to increasing microbial load above threshold levels within the body systems. This agrees with the report of Hoglund et al. [10]. This would often result in an infected/diseased state. Hence, persons visiting these urinals stand the risk of contracting opportunistic infections / diseases. Indiscriminate urination in public areas is a common practice in developing countries.

The high values of the physicochemical parameters observed in the urine contaminated soil is in agreement with the results of a similar study conducted by Dedeke et al. [11]. The major physical impact of urine deposition on soil is the significantly lower $\mathrm{pH}$, indicating high soil acidity. This is as the result of microbial oxidative process of urea which takes place in urine contaminated soil. The high acidity will greatly interfere with nutrient cycling between soils, air and water to the extent that higher deposition and dissolution of nutrients will occur in urine contaminated soil, hence the significantly higher content of $\mathrm{PO}_{4}$, $\mathrm{NO}_{3}$ and $\mathrm{SO}_{4}$ recorded from urine contaminated soil. It was earlier revealed that when soils become acidic their capacity to adsorb cations is reduced, hence the loss of such cations from the soils by leaching while N, P and S remain immobilised for longer in the soil organic matter. Furthermore, the form of nitrogen taken up by plant roots may be NH4+ instead of NO3- because nitrification is inhibited. All these and the increased deposition of cations such as $\mathrm{Al}$ and $\mathrm{Mn}$ results in the creation of adverse growth environment for both flora (micro) and fauna (micro, meso and macro) in urine contaminated soils therefore, leading to their death and possibly migration.

\section{Conclusion}

Urine contaminated soils are public health hazards which are avenues for transmission of infection from one person to another. Poor hygienic habits, overpopulation and overstretched facilities encourage indiscriminate urination in public places. This practice can either increase or decrease the microflora of urine contaminated soils. An increase in microbial load in such soil environments may result in increased probability of contracting opportunistic infections. Available toilet facilities within the university fall far below that required to cater for the ever growing population of students admitted, and staff employed, hence the attendant result of damage of available toilet facilities, and indiscriminate urination around the hostels. The provision of more and adequate toilet facilities within the institution cannot be overemphasized. As a result of poor sanitary habits and practices of most students, and to prevent overstretching of toilet facilities, students' toilets could be separated from staff toilets. Water closet toilet type and/or mobile toilets could also be made available. Contents of the mobile toilets must however, be disposed of at regular intervals. The importance of public 
investment in basic sanitation is incontestable. According to WHO/UNICEF, the practice and enforcement of basic sanitation rules would help prevent unnecessary deaths and protect the health of millions of persons

\section{References}

1. Dada EO, Aruwa CE (2014) Microorganisms associated with urine contaminated soils around lecture theatres in Federal University of Technology, Akure, Nigeria. International Journal of Applied Microbiology and Biotechnology Research 2(6): 79-85.

2. Joanne MW, Linda MS, Christopher JW (2008) Prescott harley and Klein`s microbiology. ( $7^{\text {th }}$ edn), McGraw Hill, USA, pp. 1088.

3. Lentner C,WinkA (2011) Characterization of sludge in urine separating sewage system. In: KLove B, Jenssen P, Maehlum, T (Eds.), Proceedings of the 14th International conference on Managing the Waste water resource. Ecological engineering for Waste water Treatment. Norway.

4. Jönsson H, Vinnerås B, Höglund C, Stenström TA, Dalhammar G, et al. (2000) Recycling source separated human urine. Sweden.

5. Madigan M, Martinko J (2005) Brock biology of microorganisms. (11 edn), Prentice Hall, USA.

6. Greenblat CL, Baum J, Klein BY, Nachshon S, Koltunov V, et al. (2004) Micrococcus luteus- Survival in amber. Microb Ecol 48(1): 120-127.

7. Logan NA (2005) Bacillus anthracis, Bacillus cereus, and other aerobic endospore-forming bacteria. In: Boriello SP, Murray PR, Funke G (Eds.), Topley and Wilson's microbiology and microbial infections. Bacteriol (2): 922-952.

8. Bridge, P, Spooner B (2001) Soil fungi: Diversity and detection. Plant and Soil 232(1-2): 147-154.

9. Cheesebrough M (2006) District laboratory practice in tropical countries. ( $2^{\text {nd }}$ edn), Cambridge University press, UK, pp. 434.

10. Hoglund C, Ashbolt N, Strenstrom TA (2012) Microbial risk assessment of source-separated urine used in agriculture. Waste Manag Res 20(2): 162-117.

11. Dedeke GA, Ademolu KA, Ogunnaike O, Fadeyi MO, Otti CN (2011) Impact of Human Urine Contamination on Soil Biota. Proceedings of the Environmental Management Conference, Federal University of Agriculture, Nigeria, pp. 1-8.

Your next submission with Juniper Publishers will reach you the below assets

- Quality Editorial service

- Swift Peer Review

- Reprints availability

- E-prints Service

- Manuscript Podcast for convenient understanding

- Global attainment for your research

- Manuscript accessibility in different formats ( Pdf, E-pub, Full Text, Audio)

- Unceasing customer service

Track the below URL for one-step submission https://juniperpublishers.com/online-submission.php 